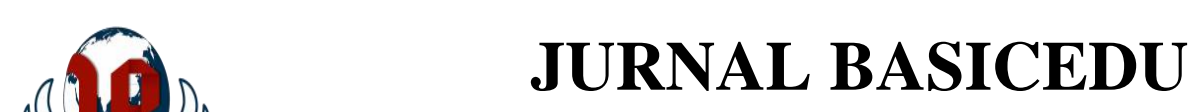

Volume 5 Nomor 3 Tahun 2021 Halaman 1286-1293

Research \& Learning in Elementary Education https://jbasic.org/index.php/basicedu

\title{
Perbedaan Keterampilan Berpikir Logis Dengan Menggunakan Bahan Ajar Sains Terintegrasi Matematika Berbasis Masalah Dengan Model CTL Dalam Pembelajaran IPA
}

\author{
Mona Monita ${ }^{1}$, Yanti Fitria ${ }^{2 凶}$ \\ Program Studi Pendidikan Dasar, Universtas Negeri Padang ${ }^{1,2}$ \\ E-mail: mona.monita4455@gmail.com ${ }^{1}$, yanti_fitria@ fip.unp.ac.id ${ }^{2}$
}

\begin{abstract}
Abstrak
Pembelajaran pada perguruan tinggi dilakukan dengan memisahkan pembelajaran sains dan matematika padahal kedua materi tersebut dapat diintergrasikan. Kondisi ini membuat masih rendahnya kemampuan berpikir logis mahasiswa PGSD di salah satu LPTK di Sumatera. Penelitian ini bertujuan untuk mengetahui bagaimana perbedaan kemampuan berpikir logis mahasiswa yang diajarkan dengan menggunakan bahan ajar sains terintegrasi matematika berbasis masalah dengan model Contextual Teaching and Learning (CTL). Metode penelitian yang dipakai adalah metode eksperimen dengan pendekatan komparatif serta rancangan penelitian menggunakan factorial design. Instrumen yang digunakan untuk mengumpulkan data dalam penelitian ini adalah lembar tes soal kemampuan berpikir logis mahasiswa. Hasil penelitian yang menunjukan rata-rata kemampuan berpikir logis bahan ajar sains terintegrasi matematika berbasis masalah yaitu 83,55 dengan Ngain 0,76, sementara rata-rata kelas dengan model CTL 69,58 dengan Ngain 0,60. Jadi kesimpulan yang diperoleh adalah terdapat perbedaan kemampuan berpikir logis mahasiswa yang mana kemampuan berpikir logis mahasiswa yang menggunakan bahan ajar sains terintegrasi matematika berbasis masalah lebih tinggi daripada kemampuan berpikir logis mahasiswa yang menggunakan model CTL.
\end{abstract}

Kata Kunci: Keterampilan Berpikir Logis, Bahan ajar terintegrasi matematika, PBL, CTL

\begin{abstract}
Learning in university is carried out by separating science and mathematics learning whereas the two subjects can be integrated. It makes students' logical thinking skill at PGSD Padang State University is still low. This study aims to find out the difference of the effect between problem-based mathematics integrated science teaching materials with the CTL model on students' logical thinking skills in the PGSD department. The research method used was an experimental method with a comparative approach with a factorial design. The instrument used to collect the data in this study was test sheet for students' logical thinking skills. The results obtained show that there are differences in students' logical thinking abilities, in which the logical thinking skills of students who were taught using problem-based integrated mathematics science teaching materials are higher than the logical thinking skills of students who were taught using the CTL model. This is evidenced by the results of the research that show the average score of students' logical thinking skills in problem-based mathematics integrated science teaching materials is 83.55 with Ngain 0.76, while those with the CTL model is 69.58 with Ngain 0.60.
\end{abstract}

Keywords: Logical Thinking Skills, integrated mathematics teaching materials, PBL, CTL

Copyright (c) 2021 Mona Monita, Yanti Fitria

Corresponding author :

Email : yanti fitria@fip.unp.ac.id

DOI : https://doi.org/10.31004/basicedu.v5i3.906

ISSN 2580-3735 (Media Cetak)

ISSN 2580-1147 (Media Online) 
1287 Perbedaan Keterampilan Berpikir Logis Dengan Menggunakan Bahan Ajar Sains Terintegrasi Matematika Berbasis Masalah Dengan Model CTL Dalam Pembelajaran IPA - Mona Monita, Yanti Fitria

DOI : https://doi.org/10.31004/basicedu.v5i3.906

\section{PENDAHULUAN}

Pendidikan merupakan hal yang paling utama dan paling penting yang harus dimiliki oleh setiap individu, dan meratakan kemajuan pada suatu bangsa, serta merupakan kebutuhan dalam kehidupan setiap manusia (Wahyuni, 2012). Pendidikan dapat mengubah peserta didik ke arah yang lebih baik, seperti dapapt mengubah kepribadian, keterampilan dan perkembangan intelektual peserta didik ke arah yang lebih baik (Jatmiko, 2015). Pendidikan memiliki sifat yang mutlak, artinya pendidikan merupakan suatu keharusan dan kewajiban agar setiap manusia mendapat pendidikan yang layak (Lasmawan, 2015). Salah satu upaya pemerintah dalam melaksanakan pendidikan yang dapat mengubah peserta didik kearah yang lebih baik adalah dengan mempersiapkan calon guru yang berkualitas, dimulai dari jenjang perguruan tinggi.

Guru adalah sebuah profesi, sehingga untuk menjadi seorang guru, seseorang perlu dilatih dengan menempuh pendidikan dengan cara yang khusus. Dengan kata lain, pekerjaan sebagai guru tidak dapat dilakukan oleh sembarang orang. Kompetensi dan profesionalisme tersebut dapat diperoleh setelah mahasiswa memperoleh gelar S1 dan akan diangkat menjadi guru. Selanjutnya, kompetensi dan profesionalisme juga harus dibentuk dan dikembangkan selama mahasiswa calon guru menjalani S1 di perguruan tinggi (Subhan \& Pamungkas, 2017). Upaya pengembangan profesionalitas guru sangat besar penting untuk berkelanjutan. Seorang guru yang tinggi kompetensi profesional harus mampu mendemonstrasikan semua aspek kompetensi bersinergi satu sama lain. Aspek penguasaan akademik mempelajari atau penguasaan materi pembelajaran sangat penting dalam transformasi pengajaran dan pembelajaran proses untuk pelajar (Yanti Fitria, 2016).

Temuan observasi disertai hasil tes kemampuan awal yang telah dilakukan pada mahasiswa pendidikan dasar Universitas Negeri Padang, didapatkan hasil bahwa mahasiswa PGSD UNP masih belum menggunakan kemampuan berpikir logis dalam memecahkan masalah yang dihadapinya. Hal ini terlihat dari rata-rata kemampuan berpikir logis setiap soal dari seluruh mahasiswa hanya 5 soal yang di atas 70 dengan persentase hanya $40 \%$ soal yang dijawab dengan benar, dan dari 41 mahasiswa, hanya 1 orang yang mencapai nilai 70 untuk tes kemampuan awal. Berpikir logis atau berpikir runtun didefinisikan sebagai proses mencapai kesimpulan menggunakan penalaran secara konsisten, berpikir sebab akibat, berpikir menurut pola tertentu atau aturan inferensi logis atau prinsip-prisnsip logika untuk memperoleh kesimpulan, dan berpikir yang meliputi induksi, deduksi, analisis, dan sintesis (Hidayat \& Sumarmo, 2013)

Rendahnya kemampuan berpikir logis mahasiswa juga disebabkan olah proses pembelajaran di perguruan tinggi kurang berorientasi pada masalah, dimana mahasiswa tidak diberikan persoalan yang real atau nyata. Dimana mahasiswa diberi tugas untuk dijadikan materi yang harus ditampilkan di depan kelas, kemudian mahasiswa lain hanya mendengarkan presentasi. Tetapi, tugas yang diberikan biasanya tidak dimaknai oleh mahasiswa dan hanya copy and paste di internet saja, tidak melibatkan siswa secara nyata ke dalam masalah yang ada. Pembelajaran yang dilakukan juga kurang memiliki makna terhadap mahasiswa, hal ini karena mahasiswa tidak mengkontruksi sendiri pengetahuan dan keterampilan yang didapatnya. Permasalahan ini muncul disebabkan karena mahasiswa tidak terlibat secara aktif dalam proses perkuliahan, dimana apabila mahasiswa lain melakukan presentasi di depan kelas, mahasiswa yang lain hanya mendengarkan saja.

Salah satu cara untuk menanggulangi masalah-masalah yang ditemukan di lapangan adalah dengan melakukan pembelajaran sains yang terintegrasi dengan matematika agar pembelajaran dapat bermakna adalah dengan menggunakan bahan ajar yang berbasis pada masalah atau menggunakan Problem Based Learning $(P B L)$, dan penerapan Contextual Teaching and Learning (CTL). Proses perkuliahan di perguruan tinggi, diperlukan bahan ajar yang mengintegrasikan sains dan matematika serta dapat digunakan oleh mahasiswa yang dapat mendorong mahasiswa untuk dapat melakukan proses perkuliahan yang mencakup masalah yang dekat dengan kehidupannya dan memiliki pembelajaran bermakna dalam proses perkuliahan. Hal ini juga dapat didukung dengan menerapkan model pembelajaran berbasis masalah dan CTL yang memiliki tujuan yang sama dengan tujuan yang ingin dicapai. 
1288 Perbedaan Keterampilan Berpikir Logis Dengan Menggunakan Bahan Ajar Sains Terintegrasi Matematika Berbasis Masalah Dengan Model CTL Dalam Pembelajaran IPA - Mona Monita, Yanti Fitria

DOI : https://doi.org/10.31004/basicedu.v5i3.906

Dalam pendidikan, integrasi sains dan matematika telah lama menjadi sorotan dalam dunia pendidikan. Perkembangan ilmu sains, matematika, dan teknologi pada abad 21 ini menjadi faktor yang dapat memicu adanya integrasi sains dan matematika. Telah banyak studi yang dibuat berkenaan dengan integrasi antar dua disiplin ilmu. Berlin dan White (Kurt \& Pehlivan, 2013) mendefenisikan bahwa integrasi sains dan matematika sebagai gabungan dua bagian dalam suatu jalur yang tidak dapat dipisahkan dari satu dengan yang lainnya. secara garis besar, dapat disimpulkan bahwa integrasi antara sains dan matematika sangat cocok dilakukan karena ranah aplikasi dan kesamaan dalam pendekatan yang dilakukan, yaitu pendekatan saintifik melalui pemecahan masalah. Sains juga dapat meningkatkan keterampilan berpikir logis peserta didik. Dalam penelitian ini, sains terintegrasi matematika yang dimaksud adalah sains yang termasuk dalam mata kuliah Konsep Dasar IPA SD yang memiliki materi-materi yang telah disusun dalam silabus perkuliahan dan akan diintegrasikan dengan mata kuliah matematika dengan memilih materi yang dapat diintegrasikan dalam bahan ajar sains terintegrasi matematika berbasis masalah.

Berbasis masalah pada penelitian ini dimaksudkan dengan menggunakan Problem Based Learning (PBL). Problem Based Learning merupakan model pembelajaran yang berdasarkan pada masalah. Dengan pembelajaran yang dimulai dari masalah, siswa belajar suatu konsep dan prinsip sekaligus memecahkan masalah (Setyaningsih, Agoestanto, \& Kurniasih, 2014). Tahap pembelajaran diawali dengan pemberian masalah, dilanjutkan dengan mengidentifikasi masalah, peserta didik melakukan diskusi untuk menyamakan presepsi tentang masalah, kemudian merancang penyelesaian dan target yang akan dicapai diakhir pembelajaran. Langkah selanjutnya peserta didik mengumpulkan sebanyak mungkin sumber pengetahuan yang bisa didapatkan dari buku, internet, bahkan observasi (Kristina \& Radia, 2021). Problem Based Learning (PBL) diketahui dapat meningkatkan prestasi dan aktivitas belajar mahasiswa PGSD karena melibatkan penilaian terhadap pendidik serta aktivitas belajar yang mumpuni untuk peningkatan prestasi belajar mahasiswa (Yanti Fitria, 2019). Hasil penelitian berikutnya dari (Sari, Ahda, \& Fitria, 2019) menunjukkan bahwa model Problem Based Learning merupakan model yang dapat membuat aktivitas peserta didik lebih dominan selama proses pembelajaran di kelas. Peserta didik dapat mencari informasi sendiri dan belajar secara berkelompok sehingga pembelajaran dapat lebih bermakna dan memancing peserta didik untuk lebih berpikir pada tingkat yang lebih tinggi. Lebih jauh, pada penelitian yang dilakukan oleh (Nofziarni, Fitria, \& Bentri, 2019), didapatkan kesimpulan bahwa hasil belajar peserta didik yang telah diterapkan model PBL tergolong dalam kriteria yang sangat tinggi, dimana rata-rata peserta didik di kelas eksperimen naik secara signifikan. Dari beberapa pendapat di atas, dapat disimpulkan bahwa pembelajaran berbasis masalah (problem based learning) adalah model pembelajaran yang berdasarkan pada masalah-masalah praktis yang memiliki konteks dengan dunia nyata yang dirancang untuk mengembangkan pemikiran, pemecahan masalah dan kemampuan intelektual peserta didik. Dalam penelitian ini, yang masalah yang dimaksud adalah permasalahan yang disediakan dalam bahan ajar sains terintegrasi matematika, dimana bahan ajar tersebut telah dikembangkan dengan menggunakan model pembelajaran berbasis masalah, dan masalah yang tersedia merupakan masalah konkret yang ada disekitar mahasiswa.

Dalam penelitian yang dilakukan oleh (Winarti, 2015), dikatakan bahwa model lain yang dapat meningkatkan kemampuan berpikir siswa adalah model CTL. Hal ini terlihat dari hasil yang didapat dalam penelitiannya, dimana pembelajaran dengan Contextual Teaching and Learning (CTL) di kelas eksperimen lebih efektif dibandingkan dengan kelas control. Lalu, dari lima indikator kemampuan berpikir kreatif yaitu berpikir lancar, fleksibilitas, orisinalitas, elaborasi dan evaluasi pada kelas eksperimen yang menggunakan Contextual Teaching and Learning (CTL) ternyata mempunyai nilai yang lebih tinggi dibandingkan kemampuan berpikir kreatif siswa kelas control.

Contextual Learning (CTL) merupakan pembelajaran yang membantu tenaga pendidik dalam mengaitkan antara materi yang diajarkan dengan situasi dunia nyata peserta didik dan mendorong peserta didik untuk 
membuat hubungan antara pengetahuan yang dimiliki dengan penerapan dalam kehidupan sehari-hari (Abdi, 2011). Hal ini sejalan dnegan pendapat menyatakan contextual teaching and learning adalah model pembelajaran yang mendorong siswa untuk ikut aktif dalam belajar dan mengajak siswa dengan situasi kehidupan nyata. CTL adalah sebuah model yang dapat membantu tenaga pendidik agar dapat mengaitkan antara materi yang dipelajari dengan situasi dunia nyata peserta didik, agar peserta didik mengalami sendiri pembelajaran sehingga pembelajaran yang dilakukan dapat menjadi pembelajaran bermakna. Dalam penelitian ini, CTL yang dimaksud adalah penelitian yang dapat menimbulkan pembelajaran bermakna bagi mahasiswa dengan menerapkan langkah-langkah dari CTL.

Bertitik tolak dari permasalah di atas, maka penulis melakukan penelitian yang berjudul "Perbedaan Keterampilan Berpikir Logis dalam Pembelajaran dengan Menggunakan Bahan Ajar Sains Terintegrasi Matematika Berbasis Masalah dengan Model CTL dalam Pembelajaran IPA di PGSD".

Pemilihan bahan ajar dengan menggunakan model PBL dan CTL dalam penelitian ini dipilih berdasarkan penelitian terdahulu belum terdapat hasil penelitian tentang perbedaan kemampuan berpikir kritis mahasiswa. Beberapa penelitian yang telah dilakukan sehubungan dengan model PBL dan CTL sebelumnya adalah: penelitian tentang model PBL yang berpengaruh positif terhadap kemampuan berpikir kritis dari perolehan siswa pada pelajaran IPA (Utama \& Kristin, 2020); penelitian tentang model PBL yang memiliki hasil belajar tematik lebih tinggi daripada menggunakan metode konvensional di sekolah dasar (Ilahi, Montessori, \& Suryana, 2020); penelitian tentang model CTL yang memiliki pengaruh signifikan terhadap motivasi belajar siswa (Alpian, Anwar, \& Puspawati, 2019). Berdasarkan kajian teoritis dan empiris, maka penelitian ini bertujuan untuk mengetahui perbedaan kemampuan berpikir kritis antara mahasiswa yang diberikan bahan ajar sains terintegrasi matematika berbasis masalah dengan mahasiswa yang diterapkan model Contextual Learning (CTL).

\section{METODE}

Penelitian ini dilakukan dengan metode penelitian eksperimen dengan pendekatan komparatif. Rancangan penelitian ini menggunakan factorial design. "Metode eksperimen merupakan metode penelitian yang digunakan untuk mencari pengaruh perlakuan tertentu terhadap yang lain dalam kondisi yang dikendalikan" (Sugiyono, 2019). Populasi yang pada penelitian ini adalah seluruh mahasiswa Pendidikan Guru Sekolah Dasar di Universitas Negeri Padang tahun ajaran 2018/2019. Pengambilan sampel dari populasi akan dilakukan dengan teknik Simple random sampling. Simple random sampling atau yang biasa disebut dengan istilah teknik acak sederhana. Dalam penelitian ini, terdapat dua variabel bebas, yang menjadi variabel bebas (independent variable) adalah penggunaan bahan ajar sains terintegrasi matematika berbasis masalah $\left(\mathrm{X}_{1}\right)$ dan dan model Contextual Learning $\left(\mathrm{X}_{2}\right)$ dengan variabel terikat (dependent variable) adalah kemampuan berpikir logis. Komponen dalam berpikir logis adalah dapat mengontrol variabel, penalaran proporsional, penalaran probabilistic, penalaran korelasional, dan penalaran kombinatorik. Dimana juga dapat meliputi kemampuan membuat kesimpulan sesuai dengan proporsi, perkiraan dengan peluan, berdasarkan korelasi, dan dibuktikan dengan menyusun analisa dan sintesa dari beberapa kasus. Instrumen yang digunakan untuk mengumpulkan data dalam penelitian ini adalah lembar tes soal. Tes digunakan untuk mengukur kemampuan berpikir logis mahasiswa.

\section{HASIL DAN PEMBAHASAN}

Penelitian ini mengenai perbedaan kemampuan berpikir logis mahasiswa yang diajarkan dengan menggunakan bahan ajar sains terintegrasi matematika berbasis masalah dengan model CTL di Universitas Negeri Padang tahun ajaran 2018/2019. Masalah pada penelitian ini mengenai kemampuan berpikir logis 
1290 Perbedaan Keterampilan Berpikir Logis Dengan Menggunakan Bahan Ajar Sains Terintegrasi Matematika Berbasis Masalah Dengan Model CTL Dalam Pembelajaran IPA - Mona Monita, Yanti Fitria

DOI

mahasiswa dilihat dari tes kemampuan berpikir logis yang ditinjau dengan menggunakan bahan ajar sains terintegrasi matematika berbasis masalah dengan model CTL. Sebelum diberikan perlakuan dilakukan tes awal untuk melihat kemampuan mahasiwa diperoleh nilai rata-rata yakni 29,17 dan 23,75. Dengan kata lain, kemampuan awal pada kedua kelompok hampir setara. Setelah diberikan dua pembelajaran di kelas yang berbeda dengan model pembelajaran yang berbeda pula, mahasiswa diberikan tes kemampuan berpikir logis.

Hasil penelitian yang diperoleh kemampuan berpikir logis mahasiswa yang menggunakan bahan ajar sains terintegrasi matematika berbasis masalah lebih tinggi daripada kemampuan berpikir logis mahasiswa yang menggunakan model CTL. Hal ini diuktikan dari hasil penelitian yang menunjukan rata-rata kemampuan berpikir logis bahan ajar sains terintegrasi matematika berbasis masalah yaitu 83,55 , smeentara rata-rata kelas dengan model CTL 69,58. Tidak hanya itu saja, perolehan nilai $\mathrm{N}$ gain juga berbeda dimana Ngain kelas eksperimen I dengan kategori tinggi, sedangkan kelas eksperimen II dalam kategori baik.

\section{Tabel 1}

\section{Data Kemampuan Berpikir Logis Mahasiswa Dikels Eksperimen I dan Eksperimen II}

\begin{tabular}{|c|c|c|c|c|c|c|}
\hline Kelas & Hasil & $\mathbf{N}$ & $\bar{x}$ & $g$ & $\underset{\max }{\mathbf{G}}$ & $\underset{\mathbf{m i n}}{\mathbf{G}}$ \\
\hline \multirow[t]{2}{*}{ Eksperimen I } & Pretest & \multirow{2}{*}{16} & 29,17 & \multirow{2}{*}{0,76} & \multirow{2}{*}{1,00} & \multirow{2}{*}{0,43} \\
\hline & Postest & & 83,33 & & & \\
\hline \multirow[t]{2}{*}{ Eksperimen II } & Pretest & \multirow{2}{*}{20} & 23,75 & \multirow{2}{*}{0,60} & \multirow{2}{*}{0,90} & \multirow{2}{*}{0,25} \\
\hline & Postest & & 69,58 & & & \\
\hline
\end{tabular}

Hasil penelitian ini diperkuat dengan penelitian yang dilakukan oleh Rangkuti dkk (2021) yang memperoleh perhitungan pos-test kelas eksperimen model pembelajaran Sains Terintegrasi Matematika Berbasis Masalah (rata-rata 50,03), menunjukkan nilai lebih tinggi dibandaingkan dengan kelas kontrol yang menggunakan model pembelajaran konvensional (rata-rata 43,89) dikarenakan model pembelajaran Sains Terintegrasi Matematika Berbasis Masalah peserta didik akan lebih memahami materi dan akan lebih mudah dalam menyerap serta memproses pengetahuan secara efektif. Selanjutnya juga sejalan dengan penelitian Nisa dkk (2015) yang menyatakan penggunaan modul terintegrasi etnosains dalam pembelajaran berbasis masalah efektif terhadap kemampuan literasi sains siswa. Selanjutnya juga sejalan dengan penelitian (Y. Fitria, Helsa, Nirwana, \& Zulkarnaini, 2018) yang menyatakan bahan ajar terintegrasi sains dan matematika meningkatkan kualitas pembelajaran dengan rata-rata prestasi 63,66 dan rata-rata nilai 75,10.

Penelitian ini telah mengungkapkan bahwa bahan ajar sains terintegrasi matematika berbasis masalah dapat mempengaruhi kemampuan berpikir logis mahasiswa dalam belajar dibandingkan model CTL. Keberhasilan ini dikarenakan bahan ajar sains terintegrasi matematika berbasis masalah membuat mahasiswa belajar tidak memandang dari satu bidang ilmu namun dengan disiplin ilmu yang berbeda yakni sains dan matematika. Hal ini membuat kemampuan berpikir logis mahasiswa menjadi berkembang karena belajar dengan mengintegrasikan dari dua disiplin ilmu. Hal ini juga sejalan Helsa \& Fitria (2017) dengan pendapat menyatakan integrasi sains dan matematika akan memberikan pengalaman belajar berbasis realita yang lebih bagi peserta didik. Langkah-langkah pembelajaran dengan bahan ajar sains terintegrasi matematika berbasis masalah membuat siswa lebih aktif dalam menjawab persoalan serta bersemangat dalam memberi dan menerima materi. Hal ini terjadi sebab adanya ketertarikan dan minat siswa untuk lebih mendalami materi yang di bahas.

Tanggapan tersebut sejalan dengan kondisi yang ditemui peneliti pada saat penelitian berlangsung. Kedua kelas eksperimen terlihat aktif ketika dilaksanakan pembelajaran terlihat dari sikap merespon pertanyaan dan materi yang disampaikan dosen. Namun, pada kelas menggunakan bahan ajar sains terintegrasi matematika berbasis masalah mahasiswa Semua mahasiswa terlihat semangat dan aktif dalam pembelajaran. Hal ini dikarenakan setiap mahasiswa dalam dalam kelompok belajarnya dituntut bekerja sama. Sehingga hal ini 
1291 Perbedaan Keterampilan Berpikir Logis Dengan Menggunakan Bahan Ajar Sains Terintegrasi Matematika Berbasis Masalah Dengan Model CTL Dalam Pembelajaran IPA - Mona Monita, Yanti Fitria

DOI : https://doi.org/10.31004/basicedu.v5i3.906

memungkinkan tidak ada mahasiswa yang tidak ikut bekerja dalam kelompok belajarnya. Kondisi ini membuat perkembangnya kemampuan berpikir logis dari mahasiswa. Hal ini sejalan dengan pendapat yang menyatakan

Sedangkan siswa pada kelas dengan model CTL keaktifkan kurang dikarenakan masih terdapat mahasiswa yang kesulitan untuk mengaitkan materi pembelajaran dengan pengetahuan yang ada di benak mereka sendiri dengan menemukan hal-hal secara nyata dan menyelesaikan masalah dengan menggunakan prosedur pemecahan masalah. Sehingga hanya mahasiswa yang kemampuab berpikir logisnya baik yang bisa dengan cepat mengaitkan materi dengan konteks nyata berakibatnya adanya kesenjangan keaktifan mahasiwa. Hal ini sejalan dengan pendapat Mulyono (Permatasari \& Muslim, 2014) yang menyatakan bahwa kelemahan dari CTL ini yakni Aktifitas dan pembelajaran cenderung akan didominasi oleh peserta didik yang biasa atau senang berbicara sehingga peserta didik lainnya lebih banyak mengikuti jalan pikiran peserta didik yang senang berbicara.

Pada penelitian ini pembelajaran sains terintegrasi matematika berbasis masalah dibuat untuk materi rangkaian listrik terintegrasi logika matematika. Adapun langkah-langkahnya terdiri dari memberikan masalah kepada mahasiswa yang akan didiskusikan, mengorganisasikan mahasiswa ke dalam kelompok belajar yang heterogen, membimbing mahasiswa pada proses penyelidikan berlangsung, mempresentasikan hasil penyelidikan serta melakukan evaluasi terhadap hasil penyelidikan untuk mengetahui kesimpulan serta perbaikan pembelajaran. Langkah-langkah ini diimplementasikan pada kelas eksperimen I sehingga mendorong kemampuan berpikir logis mahasiswa dalam memahami materi. Hal ini karena mahasiswa diberi kesempatan mengambil suatu pengalaman belajar yang komprehensif dan seimbang dalam disiplin ilmu sains yang berbeda (Yanti Fitria, 2014).

Penelitian ini sangat penting dilakukan dalam hal pendidikan di perguruan tinggi dikarenakan kemampuan berpikir logis bagi mahasiswa merupakan hal yang sangat dibutuhkan, karena mahasiswa bukan hanya sekedar menerima ilmu saja, tetapi mahasiswa juga harus mengembangkan ilmu yang telah diberikan oleh dosennya. Guna meningkatkan kemampuan berpikir logis siswa, maka peneliti memberikan solusi berupa penggunaan bahan ajar sains terintegrasi matematika berbasis masalah dan menggunakan model contextual learning (CTL). Penelitian ini dilakukan hanya dilakukan pada kelas pembelajaran Konsep Dasar IPA kelas A dan kelas B di Universitas Negeri Padang tahun ajaran 2018/2019.[

\section{KESIMPULAN}

Hasil temuan penelitian dan analisis data yang telah dilakukan dapat disimpulkan bahwa terdapat perbedaan kemampuan berpikir logis mahasiswa yang diajarkan dengan menggunakan bahan ajar sains terintegrasi matematika berbasis masalah dengan model CTL. Berdasarkan Uji F nilai F hitung sebesar 10,234 sehingga terdapat perbedaan rata-rata kemampuan berpikir logis mahasiswa dengan antara bahan ajar sains terintegrasi matematika berbasis masalah dan model CTL. Adapun kemampuan berpikir logis mahasiswa dengan bahan ajar sains terintegrasi matematika berbasis masalah lebih tinggi dari pada model CTL dengan perolehan nilai Ngain bahan ajar sains terintegrasi matematika berbasis masalah adalah 0,76 sedangkan model CTL 0,60. Jadi, dapat disimpulkan bahwa kemampuan berpikir logis mahasiswa dengan menggunakan bahan ajar sains terintegrasi matematika berbasis masalah lebih tinggi daripada menggunakan model contextual learning (CTL).

\section{UCAPAN TERIMA KASIH}

Peneliti sekaligus penulis mengucapkan terimakasih kepada seluruh pihak yang telah membantu jalannya penelitian. Puji syukur kepada Tuhan Yang Maha Esa untuk setiap kemudahan yang diberikan dalam proses 
1292 Perbedaan Keterampilan Berpikir Logis Dengan Menggunakan Bahan Ajar Sains Terintegrasi Matematika Berbasis Masalah Dengan Model CTL Dalam Pembelajaran IPA - Mona Monita, Yanti Fitria

DOI : https://doi.org/10.31004/basicedu.v5i3.906

penelitian ini. Tak lupa ucapan terimakasih untuk dosen pembimbing, keluarga, dan teman-teman yang telah memberikan support secara penuh selama penelitian ini berlangsung.

\section{DAFTAR PUSTAKA}

Abdi, M. I. (2011). Contextual Teaching and Learning (CTL) dalam Pembelajaran PAI. Dinamika Ilmu, 11(1). https://doi.org/10.21093/DI.V11I1.49

Alpian, Y., Anwar, A. S., \& Puspawati. (2019). Pengaruh Model Pembelajaran Contextual Teaching and Learning (CTL) terhadap Motivasi Belajar Siswa. Jurnal Basicedu, 3(3), 894-900.

Fitria, Y. (2014). Refleksi Pemetaan Pemahaman Calon Guru SD Tentang Integrated Sains Learning. Pedagogi, XIV(2), 82-87.

Fitria, Y. (2016). Professional Competence Development Achievements In The Field Of Basic Science In Primary School Through Problem Based Integrated Science Learning Model. In International Conference on Teacher Education And Professional Development.

Fitria, Y. (2019). Mampukah Model Problem Based Learning meningkatkan Prestasi Belajar Sains Mahasiswa Calon Guru Sekolah Dasar? Can the Problem Based Learning Model Improve the Science Learning Achievement of Prospective Elementary School Teacher Students? JURNAL INOVASI PENDIDIKAN DAN PEMBELAJARAN SEKOLAH DASAR, 3, 83-91.

Fitria, Y., Helsa, Y., Nirwana, H., \& Zulkarnaini, A. P. (2018). The integration of science and math. Journal of Physics: Conference Series, 1088.

Helsa, Y., \& Fitria, Y. (2017). Pengembangan Model Pembelajaran Science ter-Integrasi Mathematics berbasis PBL. E-Tech, OO(00), XX-XX.

Hidayat, W., \& Sumarmo, U. (2013). Kemampuan Komunikasi dan Berpikir Logis Matematik serta Kemandirian Belajar: Eksperimen terhadap Siswa SMA Menggunakan Pembelajaran Berbasis dan Strategi Think-Talk-Write. Delta-Pi: Jurnal Matematika Dan Pendidikan Matematika, 2(1), 1-14.

Ilahi, F., Montessori, M., \& Suryana, D. (2020). Pendekatan Problem Based Learning (PBL) Terhadap Hasil Belajar Tematik pada Siswa Sekolah Dasar. Jurnal Basicedu, 4(4), 969-976.

Jatmiko, J. (2015). Eksperimen Model Pembelajaran Think-Pair-Share Dengan Modul(Tps-M) Terhadap Prestasi Belajar Matematika Ditinjau Dari Minat Belajar. JIPM (Jurnal Ilmiah Pendidikan Matematika), 3(2), 417-426. https://doi.org/10.25273/jipm.v3i2.511

Kristina, T. F., \& Radia, E. H. (2021). Meta Analisis Penerapan Model Problem Based Learning Dalam Meningkatkan Hasil Belajar IPA Siswa Sekolah Dasar. Jurnal Basicedu, 5(2), 524-532.

Kurt, K., \& Pehlivan, M. (2013). Integrated Programs for Science and Mathematics: Review of Related Literature.

Lasmawan, W. (2015). Pengembangan Perangkat Pembelajaran E-learning Mata Kuliah Wawasan Pendidikan Dasar, Telaah Kurikulum Pendidikan Dasar, Pendidikan IPS Sekolah Dasar, Perspektif Global dan Problematika Pendidikan Dasar. Pendidikan Indonesia, 4(1), 556-570.

Nisa, A., Sudarmin, \& Samini. (2015). Efektivitas Penggunaan Modul Terintegrasi Etnosains Dalam Pembelajaran Berbasis Masalah Untuk Meningkatkan Literasi Sains Siswa. USEJ - Unnes Science Education Journal, 4(3), 1049-1056. https://doi.org/10.15294/usej.v4i3.8860

Nofziarni, A., Fitria, Y., \& Bentri, A. (2019). Pengaruh Penggunaan Model Problem Based Learning (PBL) terhadap Hasil Belajar Siswa di Sekolah Dasar, 3(4), 2016-2024.

Permatasari, S. W. E., \& Muslim, S. (2014). Implementasi Model Pembelajaran Contextual Teaching and Learning (Ctl) Pada Standar Kompetensi Dasar Memasang Instalasi Penerangan Listrik Di Smkn 7 
1293 Perbedaan Keterampilan Berpikir Logis Dengan Menggunakan Bahan Ajar Sains Terintegrasi Matematika Berbasis Masalah Dengan Model CTL Dalam Pembelajaran IPA - Mona Monita, Yanti Fitria

DOI : https://doi.org/10.31004/basicedu.v5i3.906

Surabaya. Jurnal Pendidikan Teknik Elektro, 3(2), 47-53.

Rangkuti, S. S., Fitria, Y., \& Karneli, Y. (2021). PENGARUH MODEL PEMBELAJARAN SAINS TERINTEGRASI MATEMATIKA BERBASIS MASALAH TERHADAP SIKAP ILMIAH. EKSAKTA : Jurnal Penelitian Dan Pembelajaran MIPA, 6(1), 97-106.

Sari, R. N., Ahda, Y., \& Fitria, Y. (2019). EFFECTIVENESS OF GUIDED INQUIRY LEARNING MODELAND PROBLEM BASED LEARNING MODELON THEMATIC INTEGRATED LEARNING COMPETENCY. International Journal of Educational Dynamics, 1(2), 257-264.

Setyaningsih, T. D., Agoestanto, A., \& Kurniasih, A. W. (2014). Identifikasi Tahap Berpikir Kritis Siswa Menggunakan PBL dalam Tugas Pengajuan Masalah Matematika, 5(November).

Subhan, A., \& Pamungkas. (2017). Pengembangan Bahan Ajar Berbasis Literasi Pada Materi Bilangan Bagi Mahasiswa Calon Guru Sd. Jpsd, 3(2), 228-240.

Sugiyono. (2019). Metode Penelitian Pendidikan. Bandung: CV Alfabeta.

Utama, K. H., \& Kristin, F. (2020). Meta-Analisis Pengaruh Model Pembelajaran Problem Based Learning (PBL) Terhadap Kemampuan Berpikir Kritis IPA Di Sekolah Dasar. Jurnal Basicedu, 4(4), 889-898.

Wahyuni, S. (2012). Pengembangan Bahan Ajar Fisika Matematika Berbasis Self Regulated Learning Sebagai Upaya. Jurnal Pendidikan Fisika Indonesia (Indonesian Journal of Physics Education), 8(1), 33-40. https://doi.org/10.15294/jpfi.v8i1.1992

Winarti. (2015). Contextual Teaching and Learning (Ctl) Untuk Meningkatkan Kemampuan Berpikir Kreatif Siswa. Jurnal Pendidikan Fisika Dan Keilmuan (JPFK), 1(1), 1-8. 